\title{
Study of the Antioxidant Power of the Waste Oil from Palm Oil Bleaching Clay
}

\author{
Katiane Cunha de Melo ${ }^{1}$, Ingrid Silva de Oliveira ${ }^{1}$, Luiza Helena de Oliveira Pires ${ }^{2}$, \\ Luís Adriano Santos do Nascimento ${ }^{1}{ }^{\mathbb{D}}$, José Roberto Zamian ${ }^{1}$, Geraldo Narciso da Rocha Filho ${ }^{1}$, \\ Marcele Fonseca Passos ${ }^{1}$, Alessandra Santos Lopes ${ }^{3}$, Attilio Converti ${ }^{4}(\mathbb{D}$ and \\ Carlos Emmerson Ferreira da Costa ${ }^{1, *}$ \\ 1 Laboratory of Oils of the Amazon, Federal University of Pará, Pará 66075-110, Brazil; \\ katiane.melo@outlook.com (K.C.d.M.); ingridcifit@hotmail.com (I.S.d.O.); \\ adrlui1@yahoo.com.br (L.A.S.d.N.); zamian@ufpa.br (J.R.Z.); narciso@ufpa.br (G.N.d.R.F.); \\ cellepassos@gmail.com (M.F.P.) \\ 2 School of Application, Federal University of Pará, Pará 66077-585, Brazil; luizapires@ufpa.br \\ 3 Laboratory of Science, Technology and food Engineering, Federal University of Pará, Pará 66075-110, Brazil; \\ alessalopes@ufpa.br \\ 4 Department of Civil, Chemical and Environmental Engineering, University of Genoa, I-16145 Genoa, Italy; \\ converti@unige.it \\ * Correspondence: emmerson@ufpa.br; Tel.: +55-91-981111883
}

Received: 20 November 2019; Accepted: 30 December 2019; Published: 12 February 2020

\begin{abstract}
Palm oil is one of the most consumed oils, one of whose refining steps is the removal of pigments and other substances using bleaching clay as adsorbent. Worldwide production of this oil was 70 million tons in 2017, requiring $1 \mathrm{t}$ of clay to produce $1000 \mathrm{t}$ of refined oil. The residual bleaching clay, having an oil fraction $(12.70 \%)$ rich in phenolics, carotenoids and tocopherols, was extracted in this study with ethanol to obtain an antioxidant-rich palm oil bleaching extract (POBE), with the aim of using it as a natural antioxidant source. The POBE antioxidant capacity determined by the DPPH method corresponded to a $20.29 \%$ inhibition of radical formation. The POBE was also tested for its potential to enhance oxidative stability of passion fruit, pracaxi and Brazil nut oils used as reference oils, and compared to common synthetic antioxidants (tert-butylhydroquinone and propyl gallate), either separately as controls or in mixtures with them. Besides the increased oxidative stability of these oils induced by the POBE, a positive synergistic effect between it and the synthetic antioxidants was observed. These results taken together suggest that the exploitation of the waste oil from bleaching clay as an additive to improve the oxidative stability of biofuels or lubricating oils is feasible.
\end{abstract}

Keywords: esmectite; residual bleaching clay; amazonian vegetable oils; bioactive compounds antioxidant; phenolic compounds; oxidation stability

\section{Introduction}

Palm (Elaeis guineensis) is grown on over 11 million hectares worldwide [1], and its oil is one of the most important branches of agribusiness in many countries. In 2017 alone, worldwide palm oil production reached around 70 million tons [2]. Because of its high content in fatty acids and substances with strong antioxidant activities, such as tocopherols, tocotrienols and carotenoids, palm oil is one of the most consumed in the world and serves a variety of sectors, among which are the food, cosmetic, biofuel and energy industries [2-5]. However, in order to meet such market demands, it is necessary to remove impurities, pigments and unpleasant odors [6] through a process known as vegetable oil 
refining, which consists of four steps: degumming, neutralizing, bleaching and deodorization. In the initial two steps, some emulsifying substances such as lecithin, free fatty acids, glycerol, carbohydrates, resins and metals are removed [7]. Bleaching is one of the most important steps of refining, during which pigments (chlorophyll and its derivatives, carotenes, tocopherols), saponifiable materials, phosphatides, phospholipids, peroxides, metals, water and so on are eliminated [8-10]. Therefore, the loss of bioactive compounds from palm oil is inevitable during the refining process.

Bleaching, also called clarification, is carried out by adsorption of oil impurities using bleaching clays as adsorbents. Due to their cation exchange, expansion and plasticity properties, as well as their large surface area, smectite clays are often used in the refining of lubricating and insulating oils with high content of pigmented materials, as well as in the removal of substances of plant origin [11]. However, the production of 1000 tons of refined oil requires approximately 1 ton of bleaching clays [12]. Saturated at the refining stage, they are disposed of in landfills, increasing costs and causing a negative environmental impact [13]. The amount of biomass and waste produced in the palm oil refining process is almost equivalent to the oil production itself. As a result, research seeks to exploit these wastes in animal feed or as fertilizers [12,14], biofuels [15] and biolubricants [16]. The recovery of bleaching clay, which contains about $20 \%-40 \%$ of vegetable oil rich in antioxidant compounds [15,17], also opens a sustainable route to the use of this residual oil to reduce lipid oxidation of oils and derivatives.

The mechanism of lipid oxidation can be described in three main steps: initiation, propagation and termination, and generating hydroperoxides and free radicals, which tend to form more stable high molecular weight end products $[18,19]$, such as insoluble oxygenated compounds. Consequently, there is thickening and formation of deposits in the oil [20], interfering with oxidative stability. Some factors such as fatty acid structure, temperature, light exposure, storage and pro-oxidizing agents may influence the mechanism of lipid oxidation. But an alternative way to retard or minimize the thermo-oxidation of oils and fats $[21,22]$ is the addition of antioxidants. Antioxidants, made up of vitamins, minerals, natural pigments, plant compounds and enzymes, inactivate free radicals by donating hydrogen atoms or electrons to these molecules. In the food industry, the most commonly used synthetic antioxidants are phenolic compounds, such as butylhydroxyanisole (BHA), butylhydroxytoluene (BHT), tert-butylhydroquinone (TBHQ) and propyl gallate (PG) $[19,23]$, which enable the donation of a proton to a free radical, regenerating the acylglycerol molecule and disrupting the lipid oxidation mechanism [24].

According to Brewer [25], natural antioxidants can circumvent the toxic and carcinogenic effects of synthetic antioxidants in humans. Preferably obtained from vegetables, which are the main source of phenolic compounds, ascorbic acid, carotenoids and tocopherols, they have a high antioxidant capacity associated mainly with the ability of the phenolic hydroxyl group to reduce reactive free radicals, such as singlet oxygen, or to decompose peroxides to phenoxyls [26]. Tocopherols and tocotrienols also inhibit the oxidation of unsaturated fatty acids [27], thus playing an important role against lipid oxidation. Crude palm oil contains $600-1000 \mathrm{mg} / \mathrm{kg}$ of tocols, about $50 \%$ of which are resistant to the palm oil refining process [28].

Considering the antioxidant potential of the main components present in the residual oil of the palm oil bleaching process, this work aimed at recycling the process adsorbent (bleaching clay) and evaluating the use of the residual oil for antioxidant purposes in poorly stable vegetable oils, namely those of passion fruit, Brazil nut and pracaxi. This approach is an innovative, economical, sustainable alternative capable of mitigating environmental impacts while reducing the production costs of the oleochemical industry.

\section{Materials and Methods}

Oils of passion fruit (Passiflora edulis) (PFO), Brazil nut (Bertholletia excelsa) (BNO) and pracaxi (Pentaclethra macroloba (Willd.) Kuntze) (PO)—used as reference oils—as well as bleaching clay were purchased from the local market. 


\subsection{Clay Characterization}

The clay crystalline structure was investigated before and after the bleaching process by Powder X-ray Diffraction (PXRD) using a X'PERT PRO MPD (PW 3040/60) diffractometer (PANalytical, São Paulo, SP, Brazil) operating with Cu radiation and a $1.54 \AA$ A wavelength. Thermal behavior was investigated by thermogravimetric and derivative analysis (TG/DTG) under synthetic air $(21 \%$ oxygen, $78 \%$ nitrogen and $1 \%$ other trace gases) at a $10{ }^{\circ} \mathrm{C} / \mathrm{min}$ heating rate, in the temperature range of $25-800{ }^{\circ} \mathrm{C}$, using a thermogravimetric analyzer, model DTG-60H (Shimadzu, Kyoto, Japan). The oil content in bleaching clay was quantified by nuclear magnetic resonance (NMR) using a Minispec mq 7.5 analyzer (Bruker Optics, Ettlingen, Germany).

\subsection{Obtaining and Characterization of Palm Oil Bleaching Extract and Vegetable Oils}

Palm oil bleaching extract (POBE) was obtained according to Fernandes et al. [29] with some modifications. Briefly, clay after bleaching was ground, mixed with $400 \mathrm{~mL}$ of ethanol, left at rest for seven days, stirred for one minute each day and finally vacuum filtered. The solvent was removed from the POBE by rotary evaporation at $40^{\circ} \mathrm{C}$.

Vegetable oils were physicochemically characterized according to the official standards of the American Oil Chemist's Society (AOCS) [30] by determining the following quality parameters: acidity index (AOCS Ca 5a-40), peroxide index (AOCS Cd 7-25), saponification index (AOCS Cd 3-25) and iodine index (AOCS Cd 1c-85). Fatty acid composition (AOCS Ce 2-66) was determined using a gas chromatograph, model GC-2010 (Shimadzu), equipped with a Flame Ionization Detector (FID) and a $30 \mathrm{~m}$-long TG-WAX MS capillary column with a $0.32 \mathrm{~mm}$ internal diameter and $0.25 \mu \mathrm{m}$ film.

\subsection{Antioxidant Activity of Palm Oil Bleaching Extract and Vegetable Oils}

Antioxidant activities of vegetable oils and POBE were determined by the 2,2-diphenyl1-picrylhydrazyl radical (DPPH) scavenging method, according to Brand-Williams et al. [31] with an Evolution Array UV-Vis spectrophotometer (Thermo Fisher Scientific, Waltham, MA, USA) at $515 \mathrm{~nm}$ wavelength. Results were expressed as percentage inhibition of radical formation $(\% I)$ in the sample compared to the initial DPPH concentration $(\% I)$, according to the equation $\% I=((A c$ $-A s)(A c) \times 100$, where $A c$ is the absorbance of the control and $A s$ that of the sample. Results were expressed as percentage inhibition of radical formation $(\% I)$ in the sample compared to the initial DPPH concentration.

Total phenolic compounds were determined according to the Folin-Ciocalteu method described by Singleton et al. [32], using gallic acid as the standard. Quantitation was performed using the above-mentioned UV-Vis spectrophotometer at $760 \mathrm{~nm}$ wavelength and the equation $\operatorname{TPC}_{(\mathrm{mgGA} / \mathrm{g})}=$ Các.gallic $\times \mathrm{V}$ volumetric balloon $(\mathrm{mL}) \times \mathrm{F} / \mathrm{m}(\mathrm{g}) \times 103$, where TPC $=$ phenolic compound concentration; Các.gallic $=$ concentration in gallic acid; $\mathrm{V}$ volumetric balloon $(\mathrm{mL})=$ extract volume after extraction; $\mathrm{F}=$ dilution factor for reading; and $\mathrm{m}=$ sample mass. Results were expressed in milligrams of eqivalent gallic acid per gram of sample (mgGAE/g).

Total carotenoids were determined according to the methodology described by Rodriguez-Amaya [33] by wavelength scanning from 300 to $600 \mathrm{~nm}$ with the above UV-Vis spectrophotometer. The $\beta$-carotene scanning spectrum showed maximum absorption at $450 \mathrm{~nm}$, which was used as a standard for quantifying carotene concentration in oils. Total carotenoid content (TC) was calculated using the $\beta$-carotene specific extinction coefficient in petroleum ether $(\varepsilon=2592)$, according to the equation $\mathrm{TC}_{(\mu \mathrm{g} / \mathrm{g})}=A s . \times 10^{4} v / m \times \varepsilon$, where As. is the absorbance; $v$ is the added petroleum ether volume in $\mathrm{mL}$; and $m=$ sample mass in $\mathrm{g}$. Results were expressed as $\mathrm{mg} / \mathrm{g}$ of total carotenoids. 


\subsection{Oxidative Stability of Vegetable Oils}

The oxidative stability of vegetable oils was determined as the oxidative induction period according to the AOCS Cd 12b-92 method using an oxidative stability instrument, model Rancimat 873 (Metrohm, Herisau, Switzerland). Water conductivity was measured along the air bubbling, which was performed at a flow rate of $10 \mathrm{~L} / \mathrm{h}$ in each oil $(5.0 \mathrm{~g})$ and a temperature of $110^{\circ} \mathrm{C}$. The oxidative induction period (OIP) was assumed as the time interval between the start of a measurement and the conductivity increase as a result of the oxidation products' solubilization. Samples of each oil were weighed and homogenized with a magnetic stirrer for $10 \mathrm{~min}$ before performing oxidative stability assays.

\subsubsection{Effect of Palm Oil Bleaching Extract or Synthetic Antioxidants}

Oxidative stability of the same oils was also determined after adding 50, 100, 200, 500, 1000 and 2000 ppm of POBE; or 50, 100 and 200 ppm of tert-butylhydroquinone (TBHQ); or, 50 and 100 ppm of propyl gallate (PG) — chosen as the reference synthetic antioxidants. The Brazilian National Health Surveillance Agency (ANVISA, 2001) Resolution RDC n ${ }^{\circ} 33 / 2001$ [34] sets maximum permitted limits of these compounds in foods of 200 and 100 ppm, respectively.

\subsubsection{Synergistic Effect of Palm Oil Bleaching Extract with Synthetic Antioxidants}

Binary mixtures were prepared using 500, 1000 and 2000 ppm POBE together with both the above synthetic antioxidants at a concentration of 50 or $100 \mathrm{ppm}$ and analyzed for their effects on the vegetable oils' oxidative stability.

\section{Results and Discussion}

\subsection{Clay Characterization before and after the Palm Oil Bleaching Process}

Clay samples before and after the palm oil bleaching process were analyzed by powder X-ray Diffractometry (PXRD) to detect any changes in the crystalline phases induced by it:

- The diffractograms shown in Figure 1 allow identifying the presence of the following clay crystalline phases both before and after bleaching: montmorillonite $\left(\mathrm{Na}_{0.3}(\mathrm{AlMg})_{2} \mathrm{Si}_{4} \mathrm{O}_{10} \mathrm{OH}_{26} \mathrm{H}_{2} \mathrm{O}\right.$-JCPDS 12-0219), illite $\left(\left(\mathrm{K}_{1} \mathrm{H}_{3} \mathrm{O}\right) \mathrm{Al}_{2} \mathrm{Si}_{3} \mathrm{AlO}_{10}(\mathrm{OH})_{2}\right.$ 一JCPDS 26-0911), kaolinite ( $\mathrm{Na}_{0.3} \mathrm{Al}_{4} \mathrm{Si}_{6} \mathrm{O}_{15}(\mathrm{OH})_{64} \mathrm{H}_{2} \mathrm{O}$-JCPDS 29-1490), quartz $\left(\mathrm{SiO}_{2}\right.$ 一JCPDS 05-490) and mica (K-Mg-Fe-Al-Si-O- $\mathrm{H}_{2} \mathrm{O}-\mathrm{JCDPS}$ 02-0227). It is possible to infer the presence of iron oxide, which indicates that there is mica in the material, while the peak at $2 \theta=27^{\circ}$ may correspond to impurities such as quartz, as suggested by Santos [35].

The clay diffractogram before bleaching (Figure 1A) agrees with what is found in the literature for the same material used for commercial anthocyanin adsorption from red cabbage [36], while that after bleaching shows a decrease in peak intensity (Figure 1B), indicating decreased material crystallinity. This result may have been due to partial dissolution of the clay crystalline lamellae after acid treatment in the bleaching process $[37,38]$. However, even after bleaching the clay structure remained practically the same, suggesting that it may be profitably reused after removal of adsorbed palm oil.

The content of clay-impregnated oil quantified by low field Nuclear Magnetic Resonance (NMR) was approximately $12.70 \%$, i.e., a lower value than reported in the literature $(20 \%-30 \%)[12,39]$, probably due to the higher efficiency of our bleaching process. 


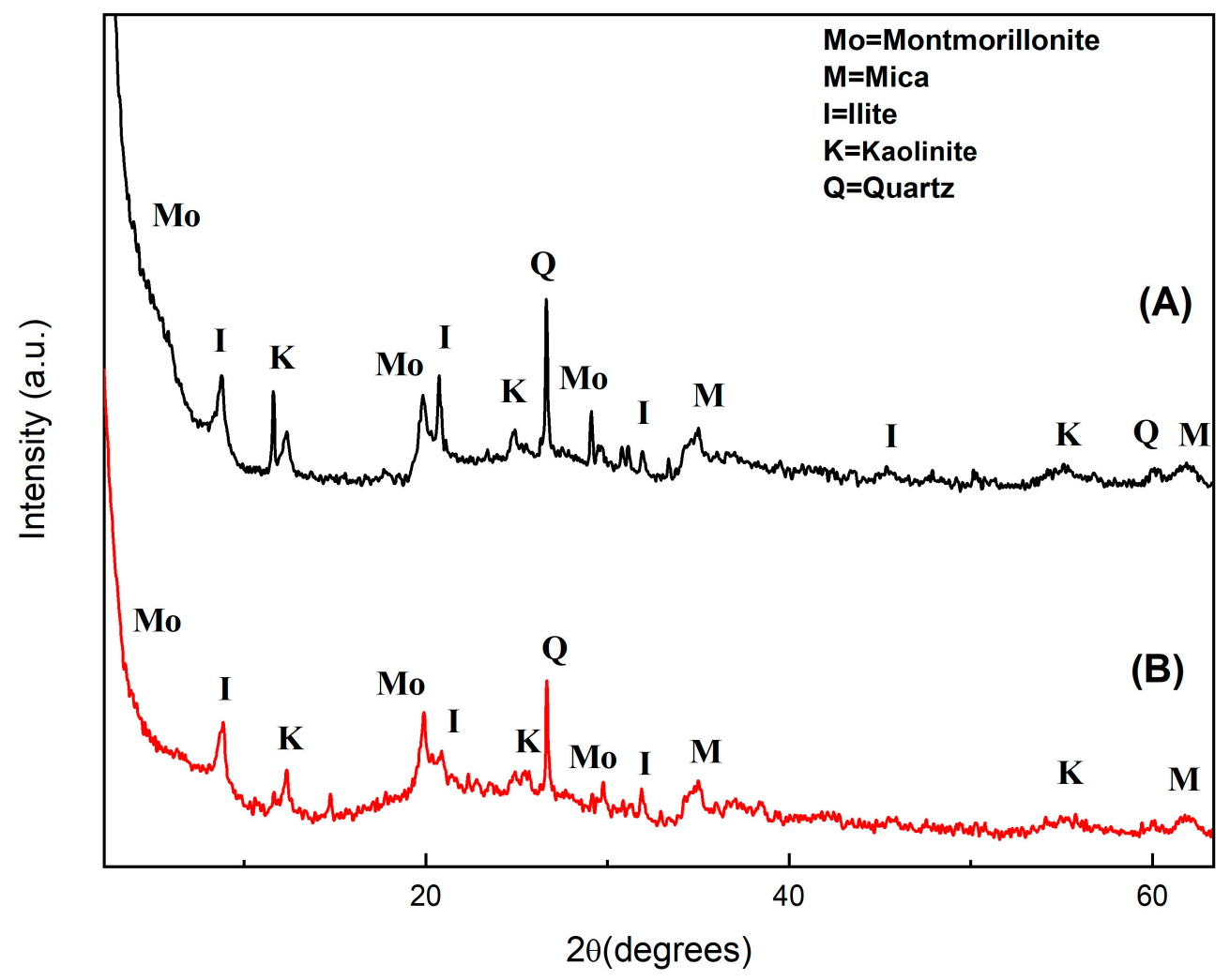

Figure 1. X-ray diffractograms of clay before (A) and after (B) palm oil bleaching.

The thermogravimetric curves of Figure 2 show a substantial difference in clay mass loss before and after treatment:

- Two peaks in the clay DTG curve can be observed before bleaching (Figure 2A) in the temperature range of $25-120{ }^{\circ} \mathrm{C}$, pointing out successive mass losses likely associated with free water evaporation and structural water loss from some mineral. A third, almost imperceptible event occurring at $120-190{ }^{\circ} \mathrm{C}$ could be attributed to the decomposition of the hydroxyl groups of compounds constituting a clay structure, such as $\mathrm{Al}(\mathrm{OH})_{3}$ and $\mathrm{Fe}(\mathrm{OH})_{2}$ [38]. Another event between 400 and $540{ }^{\circ} \mathrm{C}$ that occurred with approximately $4.6 \%$ mass loss was probably the result of the decomposition of the hydroxyl groups (structural water), mainly from kaolinite [40]. The last $2.1 \%$ mass loss observed between 550 and $700{ }^{\circ} \mathrm{C}$ is also likely to have been caused by the loss of hydroxyls from other clay minerals. Similar results were found by Miranda et al. [38] for montmorillonite clays, with a loss of $8.9 \%$ in the first event, $5.1 \%$ in the second event and $1.76 \%$ corresponding to structural dehydration.

Even TG/DTG curves of clay after bleaching highlight a first event in the range of 25 to $160{ }^{\circ} \mathrm{C}$ with $4.9 \%$ mass loss (Figure 2B), possibly due to evaporation of free water molecules, and at least two successive events in the temperature ranges of $170-270{ }^{\circ} \mathrm{C}$ and $270-340{ }^{\circ} \mathrm{C}$. Considering that between 170 and $340{ }^{\circ} \mathrm{C}$ there was no clay mass loss before bleaching (Figure 2A), the last two events may be attributed to the loss of hydroxyl groups (structural water), ions or compounds adsorbed on clay lamella, probably originating from the bleaching process $(7.1 \%)$, as well as the burning of oily organic matter adsorbed on clay (12.5\%), respectively. The latter hypothesis appears to be confirmed by the similarity of clay thermal profile after bleaching between 270 and $340{ }^{\circ} \mathrm{C}$ to those found in DTG curves of vegetable oils [22,41,42]. As expected, the $12.5 \%$ loss attributed to organic material burning is very close to the content of oil embedded in clay determined by low-field NMR (12.7\%). Finally, a last event, which occurred between 410 and $600{ }^{\circ} \mathrm{C}$, indicates successive mass losses $(6.1 \%)$ that can be attributed to clay hydroxyls, mainly kaolinite and other clay minerals [40]. 

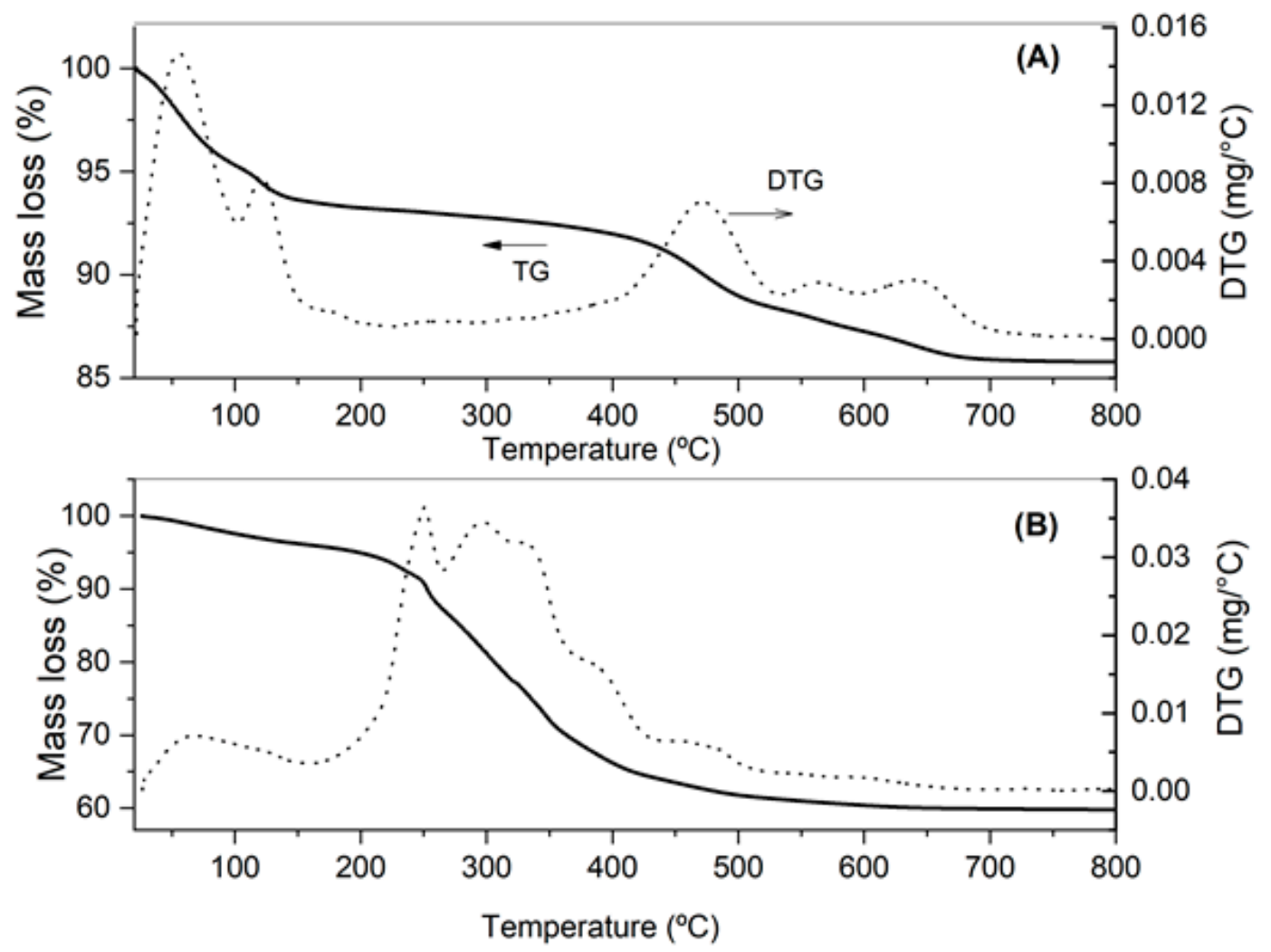

Figure 2. TG/DTG curves of clay before (A) and after (B) palm oil bleaching.

\subsection{Physicochemical Characterization of Palm Oil Bleaching Extract and Vegetable Oils}

The fatty acid profiles of passion fruit (PFO), pracaxi (PO) and Brazil nut (BNO) oils presented in Table 1 show that they consist mainly of unsaturated fatty acids, which makes them particularly susceptible to oxidation. For this reason, they were chosen to test the POBE antioxidant power.

Table 1. Fatty acid composition (\%) of the palm oil bleaching extract (POBE) compared with those of vegetable oils.

\begin{tabular}{|c|c|c|c|c|c|c|}
\hline Fatty Acid & $\begin{array}{l}\text { Passion } \\
\text { Fruit Oil }\end{array}$ & Pracaxi Oil & $\begin{array}{c}\text { Brazil Nut } \\
\text { Oil }\end{array}$ & $\begin{array}{c}\text { Crude Palm } \\
\text { Oil }\end{array}$ & $\begin{array}{l}\text { Refined } \\
\text { Palm Oil }\end{array}$ & POBE \\
\hline Myristic (C14:0) & 0.41 & 0.34 & 0.09 & 0.87 & 0.76 & 0.91 \\
\hline Palmitic (C16:0) & 10.91 & 3.09 & 14.37 & 40.42 & 35.75 & 39.82 \\
\hline Palmitoleic (C16:1) & 0.20 & 0.12 & 0.31 & 0.17 & 0.18 & 0.15 \\
\hline Stearic $(\mathrm{C} 18: 0)$ & 3.56 & 5.77 & 11.41 & 4.64 & 4.26 & 4.25 \\
\hline Oleic (C18:1) & 18.49 & 48.61 & 39.22 & 43.38 & 48.02 & 44.32 \\
\hline Linoleic (C18:2) & 64.32 & 11.81 & 33.86 & 8.85 & 9.85 & 9.13 \\
\hline Linolenic (C18:3) & 0.44 & 0.13 & 0.21 & 0.36 & 0.30 & 0.47 \\
\hline Arachidic (C20:0) & 0.32 & 3.01 & 0.49 & 0.54 & 0.54 & 0.29 \\
\hline Behenic (C22:0) & 0.65 & 14.79 & - & - & - & - \\
\hline Lignoceric (C24:0) & 0.39 & 10.88 & - & - & - & - \\
\hline Total saturated & 16.24 & 37.88 & 26.36 & 46.47 & 41.31 & 45.27 \\
\hline Total unsaturated & 83.45 & 60.67 & 73.60 & 52.76 & 58.35 & 54.07 \\
\hline
\end{tabular}

PFO had linoleic (64.32\%), oleic (18.49\%) and palmitic (10.91\%) acids as the major components. Since the first one is a polyunsaturated fatty acid, its larger content compared to other reference vegetable oils suggests higher susceptibility to lipid oxidation $[43,44]$. The same type of oxidative sensitivity, although less pronounced, would be expected for BNO, of which these acids constitute 33.86\%, 39.22\% and $14.37 \%$, respectively, in agreement with the composition reported by Rodrigues et al. [45]. On the other hand, PO had a higher content of saturated fatty acids, namely behenic (14.79\%), lignoceric 
$(10.88 \%)$ and stearic $(5.77 \%)$ acids, and a lower content of linoleic acid $(11.81 \%)$, from which higher oxidative stability would be expected.

Since palm oil refining did not significantly alter its fatty acid composition, its oxidative stability, which is generally attributed to the high concentration of saturated fatty acids [46], should not have been influenced. As expected, the residue removed from clay after bleaching had a fatty acid composition very similar to that of crude and refined palm oils, with higher percentages of oleic (44.32\%), palmitic (39.82\%), linoleic (9.13) and stearic (4.25\%) acids.

Resolution RDC No. 270/2005 of ANVISA [47] establishes maximum limits of acidity and peroxide indices of $4 \mathrm{mgKOH} / \mathrm{g}$ and $15 \mathrm{meqO} / \mathrm{kg}$, respectively, for unrefined and cold-pressed oils and fats intended for human use. These values can be compared with the basic quality parameters of vegetable oils listed in Table 2, in order to clarify possible POBE effects on their oxidative stability.

Table 2. Physicochemical characterization of reference vegetable oils.

\begin{tabular}{cccc}
\hline Property (Unit) & Passion Fruit Oil (PFO) & Pracaxi Oil (PO) & Brazil Nut Oil (BNO) \\
\hline Acidity index $(\mathrm{mgKOH} / \mathrm{g})$ & 2.0 & 3.9 & 7.0 \\
Peroxide index $\left(\mathrm{meqO}_{2} / \mathrm{kg}\right)$ & 5.9 & 8.5 & 13.0 \\
Saponification index $\left(\mathrm{mgKOH}_{\mathrm{g}}\right)$ & 146.5 & 131.0 & 121.2 \\
Iodine index $\left(\mathrm{gI}_{2} / 100 \mathrm{~g}\right)$ & 134.4 & 65.4 & 97.4 \\
Oxidative induction period $(\mathrm{h})$ & 3.40 & 1.93 & 2.10 \\
\hline
\end{tabular}

PFO and PO are in accordance with current Brazilian legislation, while BNO had a slightly higher acidity index, probably due to the presence of undesirable substances in seeds resulting from the selection or their inadequate storage [48]. High acidity indices, like that detected in BNO and to a lesser extent in PO, are indicative of a high content of free fatty acids resulting from the action of vegetable or microbial lipases [49]. Indeed, seeds of oil-rich species, such as pracaxi and Brazil nut, are especially susceptible to the action of these enzymes because of their exposition during harvesting that increases their moisture content and causes hydrolytic rancidity [50].

The higher BNO peroxide index $\left(13.0 \mathrm{meqO}_{2} / \mathrm{kg}\right)$ compared to $\mathrm{PO}\left(8.5 \mathrm{meqO}_{2} / \mathrm{kg}\right)$ and $\mathrm{PFO}$ $\left(5.9 \mathrm{meqO}_{2} / \mathrm{kg}\right.$ ) indicates a higher oxidation degree. The saponification index, which increases with decreasing the fatty acid chain length, and increasing the free fatty acids content [51], was 121.2, 146.5 and $131.3 \mathrm{mgKOH} / \mathrm{g}$ for $\mathrm{BNO}, \mathrm{PFO}$ and $\mathrm{PO}$, respectively.

The oxidative induction periods (OIPs) of $\mathrm{PO}(1.93 \mathrm{~h})$ and $\mathrm{BNO}(2.10 \mathrm{~h})$ were significantly shorter than those of PFO ( $3.40 \mathrm{~h})$, which indicates higher oxidative stability of the last oil, contrary to what was expected by the fatty acid profile. This means that not only the lipid composition, but also other quality parameters should be taken into account when assessing oxidative stability, such as the acidity and peroxide indices. Both do in fact indicate the oil state of preservation and quality, by evaluating the products resulting from lipid oxidation, i.e., the degree of deterioration. The relatively short OIP values of the three reference oils tested suggest the possibility of improving the oxidative stability of other oils and biofuels as well, by supplementing them with antioxidant-rich waste oils such as that proposed in this study.

\subsection{Bioactive Compounds and Antioxidant Activity of Palm Oil Bleaching Extract and Vegetable Oils}

The contents of bioactive compounds in the oils investigated in this work are listed in Table 3.

The contents of total phenolic compounds (TPCs) in all oils tested indicate the presence in their chemical structures of hydroxyl groups and aromatic rings, both in simple and polymeric forms, which contribute to their antioxidant power. However, this content was particularly high in crude palm oil and POBE and significantly lower in the reference vegetable oils. In addition, as expected, the lowest content was found in refined palm oil, hence demonstrating the effectiveness of the bleaching process. Therefore, it is likely that a portion of the TPCs was degraded during the oil refining process, but another one was concentrated in the POBE and clay. 
Table 3. Bioactive compounds of the palm oil bleaching extract (POBE) compared with those of other vegetable oils.

\begin{tabular}{cccc}
\hline Source of Oil & $\begin{array}{c}\text { Total Phenolic Compounds } \\
\text { (mgGAE/g) }\end{array}$ & $\begin{array}{c}\text { Total Carotenoids } \\
\text { (mg/g) }\end{array}$ & $\begin{array}{c}\text { Antioxidant Capacity } \\
\text { (DPPH॰\% Inhibition) }\end{array}$ \\
\hline POBE & 386.1 & 357.4 & 20.3 \\
Crude palm & 840.8 & 821.4 & 87.1 \\
Refined palm & 54.9 & 127.9 & 17.7 \\
Passion fruit & 118.2 & 40.6 & 4.7 \\
Pracaxi & 84.5 & 10.9 & 2.2 \\
Brazil nut & 107.6 & 36.2 & 19.8 \\
\hline
\end{tabular}

It is also possible to observe that a large amount of total carotenoids (TCs) was lost during bleaching, because the POBE had a TC value (357.4 ppm) that was almost thrice that of refined palm oil, but less than half of that of crude oil. According to Rossi et al. [52], the use of clays and synthetic silica mixtures in the bleaching process is responsible for the removal of no less than $30 \%$ to $50 \%$ of crude palm oil carotenoids, suggesting that residual oily extract could be an effective antioxidant additive. However, contrary to what is often stressed in the literature, there is no direct relationship between the TPC content and the antioxidant activity of natural products, many other causes being involved in the latter [53]. The TPC content does not determine antioxidant activity, but rather the structure of phenolic compounds. These, depending on the number and position of the hydroxyl groups, as well as replacements in their aromatic rings, may or may not present antioxidant properties [5].

Crude palm oil showed an antioxidant activity expressed as percentage inhibition of DPPH. $(87.1 \%)$ not so different from that reported in the literature $(59.02-88.16 \%)$, whose broad variability may have depended on the different industrial processes used $[54,55]$. However, the refining process led to an almost $80 \%$ decrease of this activity, confirming the literature data [55]. Although much lower than palm oil antioxidant activity, the one of the POBE (20.3\%) was about 5-10-fold those of PFO and PO, respectively, and very close to that of BNO (Table 3). Since the TPC and TC contents of PFO and $\mathrm{BNO}$ are close to each other and the OIP of the former much longer than that of the latter (Table 2), it is likely that the oxidation inhibition mechanisms of these bioactive compounds are distinct and the inhibition percentages not proportional within of the oil. For this same reason, although PO had the lowest bioactive compound contents (TPC $=84.5 \mathrm{mgGAE} / \mathrm{g} ; \mathrm{TC}=10.9 \mathrm{mg} / \mathrm{g}$ ) along with the lowest DPPH scavenging capacity (2.2\%) among the three reference oils, its OIP was not significantly shorter than that of BNO.

\subsection{Effect of Palm Oil Bleaching Extract or Synthetic Antioxidants on Vegetable Oil Stability}

POBE addition to the reference vegetable oils led to a significant OIP lenghtening at concentrations $\geq 200 \mathrm{ppm}$, although this effect was well below that observed using tert-butylhydroquinone (TBHQ) and propyl gallate (PG) as synthetic antioxidants (Figure 3), whose overall effectiveness decreased in the order $\mathrm{PFO}>\mathrm{PO}>\mathrm{BNO}$; i.e., according to the worsening of oil quality parameters (Table 2). However, the POBE performance as an antioxidant additive in PO was, when used at 1000 ppm, even better than that of synthetic antioxidants. On the other hand, the worst performance in BNO may have been the result of a different action mechanism or of its higher oxidation degree, in that bioactive compounds may have reacted with oxidation products thus reducing the POBE's protective action.

In Tables 4 and 5 it is possible to observe the influence of the POBE, in blend with synthetic antioxidants, on the OIP of vegetable oils. In general, the use of POBE in combination with PG (Table 4) or TBHQ (Table 5) increased the vegetable oils' OIP, thus demonstrating the occurrence of a synergism between them, especially in the case of PG that showed the best results. This made it possible to increase the oxidation protection of these oils without exceeding the maximum limit allowed by law for the use of synthetic antioxidants. 

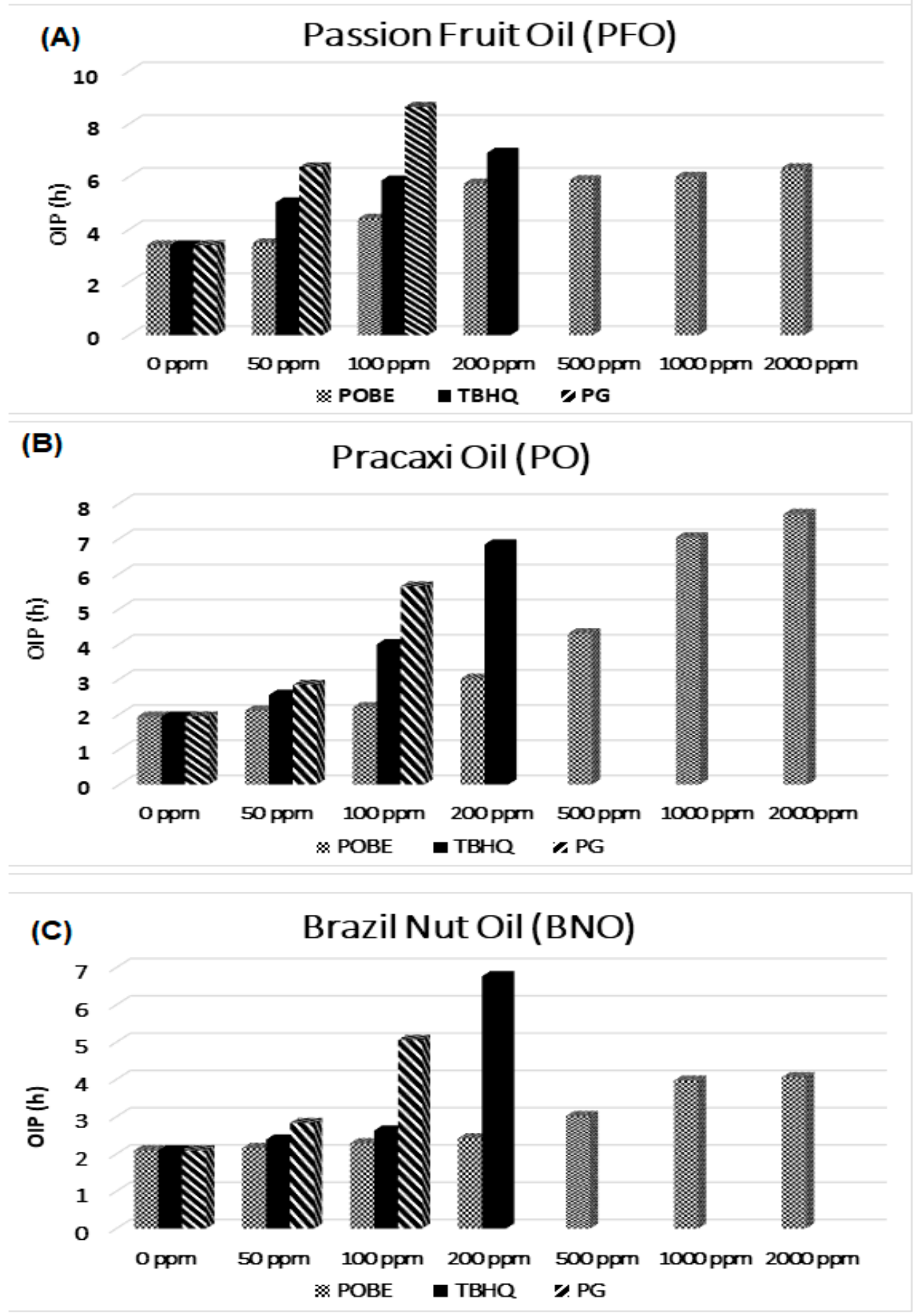

Figure 3. Rancimat induction period vs. antioxidant concentration measured at $110^{\circ} \mathrm{C}$. (A) Passion Fruit Oil (PFO); (B) Pracaxi Oil (PO); (C) Brazil Nut Oil (BNO). 
Table 4. Influence of PG/POBE (ppm/ppm) blends on the oxidative induction period (h) of reference vegetable oils.

\begin{tabular}{cccc}
\hline $\begin{array}{c}\text { PG/POBE } \\
\text { in Oil }\end{array}$ & $\begin{array}{c}\text { Passion Fruit } \\
\text { Oil (PFO) }\end{array}$ & $\begin{array}{c}\text { Pracaxi } \\
\text { Oil (PO) }\end{array}$ & $\begin{array}{c}\text { Brazil Nut } \\
\text { Oil (BNO) }\end{array}$ \\
\hline $0 / 0$ & $3.4 \pm 0.4$ & $1.9 \pm 0.2$ & $2.1 \pm 0.6$ \\
$50 / 0$ & $6.4 \pm 0.4$ & $2.8 \pm 0.8$ & $2.8 \pm 0.7$ \\
$100 / 0$ & $8.6 \pm 1.1$ & $5.6 \pm 0.6$ & $5.1 \pm 1.0$ \\
$50 / 500$ & $5.9 \pm 0.6$ & $4.7 \pm 0.3$ & $5.1 \pm 0.2$ \\
$50 / 1000$ & $6.5 \pm 1.0$ & $5.1 \pm 0.2$ & $6.1 \pm 0.2$ \\
$50 / 2000$ & $9.5 \pm 0.4$ & $7.3 \pm 0.5$ & $7.7 \pm 0.6$ \\
$100 / 500$ & $6.0 \pm 0.5$ & $9.8 \pm 0.1$ & $6.4 \pm 0.3$ \\
$100 / 1000$ & $11.1 \pm 1.0$ & $12.2 \pm 0.7$ & $11.1 \pm 1.0$ \\
$100 / 2000$ & $11.4 \pm 0.8$ & $10.5 \pm 0.4$ & $9.5 \pm 0.2$ \\
\hline
\end{tabular}

Table 5. Influence of TBHQ/POBE (ppm/ppm) blends on the oxidative induction period (h) of reference vegetable oils.

\begin{tabular}{cccc}
\hline $\begin{array}{c}\text { TBHQ/POBE } \\
\text { in Oil }\end{array}$ & $\begin{array}{c}\text { Passion Fruit } \\
\text { Oil (PFO) }\end{array}$ & $\begin{array}{c}\text { Pracaxi } \\
\text { Oil (PO) }\end{array}$ & $\begin{array}{c}\text { Brazil Nut } \\
\text { Oil (BNO) }\end{array}$ \\
\hline $0 / 0$ & $3.4 \pm 0.4$ & $1.9 \pm 0.2$ & $2.1 \pm 0.6$ \\
$50 / 0$ & $5.0 \pm 0.8$ & $2.6 \pm 0.3$ & $2.4 \pm 1.0$ \\
$100 / 0$ & $5.9 \pm 1.1$ & $4.0 \pm 0.7$ & $2.6 \pm 0.8$ \\
$50 / 500$ & $5.0 \pm 1.6$ & $3.6 \pm 0.4$ & $3.3 \pm 0.9$ \\
$50 / 1000$ & $5.7 \pm 1.2$ & $5.6 \pm 0.2$ & $4.6 \pm 0.4$ \\
$50 / 2000$ & $9.3 \pm 1.4$ & $6.0 \pm 0.3$ & $3.9 \pm 0.2$ \\
$100 / 500$ & $5.7 \pm 1.9$ & $5.5 \pm 0.4$ & $4.4 \pm 0.1$ \\
$100 / 1000$ & $8.3 \pm 0.4$ & $5.9 \pm 0.1$ & $6.4 \pm 0.5$ \\
$100 / 2000$ & $10.9 \pm 0.5$ & $8.0 \pm 0.1$ & $9.4 \pm 0.5$ \\
\hline
\end{tabular}

PFO, which displayed the best quality parameters (Table 2), was the one among the vegetable oils tested that gave the best inhibition results, even quadrupling the OIP using the 100/2000 (ppm/ppm) $\mathrm{PG} / \mathrm{POBE}$ blend. The OIP of BNO, which in contrast showed the worst quality parameters, using the 50/500 (ppm/ppm) PG/POBE blend, was almost the same as that obtained using the maximum PG concentration allowed by the legislation (100 ppm according to the Brazilian legislation (ANVISA RDC $\left.n^{\circ} 33 / 2001\right)$ ) [34]. There is no limit established for natural antioxidants, which is the case of the POBE. This allowed halving the dosage of this synthetic antioxidant, which, like all others, in large quantities can be harmful to human health. However, in the case of $\mathrm{PO}$, a progressive increase in the TBHQ/POBE dosage led to a maximum OIP threshold of about $5.5 \mathrm{~h}$, which was significantly exceeded only by using the maximum POBE dosage in the blend (Table 5).

\section{Conclusions}

The aim of this work was to recover the clay used as an adsorbent in the palm oil bleaching process and to use the residual oil extract (POBE) as an antioxidant additive in order to increase the oxidative stability of vegetable oils. For this purpose, the passion fruit, Brazil nut and pracaxi oils were tested as references for future studies on biofuels and lubricating oils. Thermogravimetric and NMR analyses of clay after bleaching indicated a $12 \%$ residual oil content, whose physicochemical characterization showed a high antioxidant potential related to its high contents of phenolic compounds and carotenoids.

The antioxidant capacity of POBE, tested at different concentrations in reference vegetable oils, was comparable to those of PG and TBHQ, which are commonly used to improve the stability of biofuels and lubricating oils. In general, starting from a POBE concentration of $200 \mathrm{ppm}$, an increase in the oxidative induction period was observed for the studied oils, which is expected to lead to an increase in their shelf life. PG showed higher efficiency than TBHQ as synthetic antioxidant, probably 
due to its larger number of active hydroxyl groups, which could have compensated the polarization effect of the aromatic ring, favoring the release of more protons.

In mixtures with these synthetic antioxidants, especially PG, the residual oil showed a positive synergistic effect on the oxidative stability of pracaxi, Brazil nut and passion fruit oils, whose oxidative induction periods, using 100/1000 (ppm/ppm) PG/POBE in oils, were lengthened to as much as 12.2, 11.1 and $11.1 \mathrm{~h}$, respectively. Such a synergistic effect make way for future replacement of these synthetic antioxidants with natural alternatives such as POBE, to minimize their negative effects on human health and, at the same time, solve the environmental problem of waste oil disposal and bleaching clay exploitation.

These results point to the future substitution of synthetic antioxidants with natural alternatives, minimizing the negative effects of these substances on human health. POBE proved to be efficient in its antioxidant capacity, adding value to residual oils from the oil refinement processes and contributing to the reduction of the environmental problem caused by the exploration of bleaching clay. These results make way for future replacement of these synthetic antioxidants with natural alternatives such as POBE.

Author Contributions: The conceptualization and data curation K.C.d.M.; investigation, K.C.d.M. and I.S.d.O.; methodology, A.S.L.; resources, J.R.Z. and G.N.d.R.F; writing—original draft preparation, K.C.d.M. and L.H.d.O.P.; writing—review and editing, L.A.S.d.N.; M.F.P;; A.C. and L.H.d.O.P.; and supervision, C.E.F.d.C. and L.H.d.O.P.; funding acquisition, J.R.Z. and G.N.d.R.F. All authors have read and agree to the published version of the manuscript.

Funding: We thank the Pará State Government and PROPESP/UFPA for financial support. This research was funded by CNPQ, grant number 432221/2018-2. This study was financed in part by the Cooedenação de Aperfeiçoamento de Pessoal de Nível Superior-Brasil (CAPES)-Finance Code 001.

Acknowledgments: The authors are thankful to the Federal University of Pará, laboratories of the UFPA School of Physics, Amazon Oil Industry and AGROPALMA for providing oils and oil bleaching clays used in this study.

Conflicts of Interest: The authors declare no conflict of interest. The funders had no role in the design of the study; in the collection, analyses, or interpretation of data; in the writing of the manuscript, or in the decision to publish the results.

\section{References}

1. Abdul Khalil, H.P.S.; Nur Firdaus, M.Y.; Anis, M.; Ridzuan, R. The effect of storage time and humidity on mechanical and physical properties of medium density fiberboard (MDF) from oil palm empty fruit bunch and rubberwood. Polym. Plast. Technol. Eng. 2008, 47, 1046-1053. [CrossRef]

2. United States Department of Agriculture. Corn and Soybean Production Costs and Export Competitiveness in Argentina, Brazil, and the United States; US Department of Agriculture: Washington, DC, USA, 2016.

3. Alimentarius Codex. Codex standard for named vegetable oils. Codex Stan 1999, 8, 11-25.

4. Nagendran, B.; Unnithan, U.R.; Choo, Y.M.; Sundram, K. Characteristics of red palm oil, a carotene- and vitamin E-rich refined oil for food uses. Food Nutr. Bull. 2000, 21, 189-194. [CrossRef]

5. Sundram, K.; Sambanthamurthi, R.; Tan, Y.-A. Palm fruit chemistry and nutrition. Asia Pac. J. Clin. Nutr. 2003, 12, 355-362.

6. O'Brien, R.D. Fats and Oils: Formulating and Processing for Applications; CRC Press: Boca Raton, FL, USA, 2008; ISBN 0849315999.

7. Rosa, G.O.; Vieira Filho, F.C.; Jorge, L.M.M.; Paraíso, P.R.; Andrade, C.M.G. Modelagem e avaliação do processo de degomagem no refino de óleo de soja. Engevista 2016, 18, 78-95. [CrossRef]

8. Rodrigues, M.G.F.; Pereira, K.R.O.; Valenzuela-Diaz, F.R. Obtenção e caracterização de materiais argilosos quimicamente ativados para utilização em catálise. Cerâmica 2006, 52, 260-263. [CrossRef]

9. Caglar, B.; Afsin, B.; Tabak, A.; Eren, E. Characterization of the cation-exchanged bentonites by XRPD, ATR, DTA/TG analyses and BET measurement. Chem. Eng. J. 2009, 149, 242-248. [CrossRef]

10. Vicari da Silva, J.O. Qualidade de Óleo de Soja Refinado Embalado em PET (Polietileno Tereftalato) Armazenado na Presença e Ausência de Luz. Master's Thesis, Universidade Católica Dom Bosco, Campo Grande, Brazil, 2013.

11. Sud Chemie do Brasil Ltda. Ficha Técnica de Produtos; Sud Chemie do Brasil Ltda: Jacareí, Brazil, 2011. 
12. Loh, S.K.; James, S.; Ngatiman, M.; Cheong, K.Y.; Choo, Y.M.; Lim, W.S. Enhancement of palm oil refinery waste-Spent bleaching earth (SBE) into bio organic fertilizer and their effects on crop biomass growth. Ind. Crops Prod. 2013, 49, 775-781. [CrossRef]

13. Krzyśko-Łupicka, T.; Cybulska, K.; Wieczorek, A.; Możdżer, E.; Nowak, M.J. The effect of spent bleaching earth ageing process on its physicochemical and microbial composition and its potential use as a source of fatty acids and triterpenes. Environ. Sci. Pollut. Res. 2014, 21, 10765-10774. [CrossRef]

14. Boukerroui, A.; Belhocine, L.; Ferroudj, S. Regeneration and reuse waste from an edible oil refinery. Environ. Sci. Pollut. Res. 2018, 25, 18278-18285. [CrossRef]

15. Loh, L.S.K.; Foon, C.S.; May, C.Y.; Ngan, M.A. A study of residual oils recovered from spent bleaching earth: Their characteristics and applications. Am. J. Appl. Sci. 2006, 3, 2063-2067.

16. Loh, S.K.; Choo, Y.M.; Ma, A.N. Residual Oil from Spent Bleaching Earth (SBE) for Biodiesel and Biolubricant Applications; MPOB: Bandar Baru Bangi, Malaysia, 2007.

17. Mandarino, J.; Hirakuri, M.; Roessing, A. Tecnologia Para Produção do Óleo de Soja: Descrição das Etapas, Equipamentos, Produtos e Subprodutos; Embrapa Soja: Londrina, Brazil, 2015.

18. Antolovich, M.; Prenzler, P.D.; Patsalides, E.; McDonald, S.; Robards, K. Methods for testing antioxidant activity. Analyst 2002, 127, 183-198. [CrossRef] [PubMed]

19. Jorge, N.; Malacrida, C.R.; Angelo, P.M.; Andreo, D. Proximal composition and antioxidant activity of the extract of passion fruit seeds (Passiflora edulis) in soybean oil. Agric. Res. Trop. 2009, 39, 380-385.

20. Adhvaryu, A.; Erhan, S.Z.; Liu, Z.S.; Perez, J.M. Oxidation kinetic studies of oils derived from unmodified and genetically modified vegetables using pressurized differential scanning calorimetry and nuclear magnetic resonance spectroscopy. Thermochim. Acta 2000, 364, 87-97. [CrossRef]

21. Wayner, D.D.M.; Burton, G.W.; Ingold, K.U.; Locke, S. Quantitative measurement of the total, peroxyl radical-trapping antioxidant capability of human blood plasma by controlled peroxidation. The important contribution made by plasma proteins. FEBS Lett. 1985, 187, 33-37. [CrossRef]

22. Pardauil, J.J.R.; de Molfetta, F.A.; Braga, M.; de Souza, L.K.C.; Filho, G.N.R.; Zamian, J.R.; da Costa, C.E.F. Characterization, thermal properties and phase transitions of amazonian vegetable oils. J. Therm. Anal. Calorim. 2017, 127, 1221-1229. [CrossRef]

23. Tiveron, A.P. Atividade Antioxidante e Composição Fenólica de Legumes e Verduras Consumidos no Brasil. Master's Thesis, Universidade de São Paulo, São Paulo, Brazil, 2010.

24. Oliveira, R.R.; Lage, M.E.; da Silveira Neto, O.J.; de Sales, M.C. Antioxidante de produtos naturais cárneos. Publ. Med. Vet. Zootec. 2012, 6, 37-39.

25. Brewer, M.S. Natural antioxidants: Sources, compounds, mechanisms of action, and potential applications. Compr. Rev. Food Sci. Food Saf. 2011, 10, 221-247. [CrossRef]

26. Nijveldt, R.J.; Van Nood, E.; Van Hoorn, D.E.C.; Boelens, P.G.; Van Norren, K.; Van Leeuwen, P.A.M. Flavonoids: A review of probable mechanisms of action and potential applications. Am. J. Clin. Nutr. 2001, 74, 418-425. [CrossRef]

27. Castelo-Branco, V.N.; Santana, I.; Di-Sarli, V.O.; Freitas, S.P.; Torres, A.G. Antioxidant capacity is a surrogate measure of the quality and stability of vegetable oils. Eur. J. Lipid Sci. Technol. 2016, 118, 224-235. [CrossRef]

28. Bobbio, P.A.; Bobbio, F.O. Quimica do Processamento de Alimentos; Livraria Varela: São Paulo, Brazil, 1992; Volume 2, ISBN 9788578110796.

29. Fernandes, D.M.; Sousa, R.M.F.; de Oliveira, A.; Morais, S.A.L.; Richter, E.M.; Muñoz, R.A.A. Moringa oleifera: A potential source for production of biodiesel and antioxidant additives. Fuel 2015, 146, 75-80. [CrossRef]

30. American Oil Chemists' Society. Official Methods And recommended Practices of the American Oil Chemists' Society, 4th ed.; AOCS: Urbana, IL, USA, 1995.

31. Brand-Williams, W.; Cuvelier, M.E.; Berset, C. Use of a free radical method to evaluate antioxidant activity. LWT-Food Sci. Technol. 1995, 28, 25-30. [CrossRef]

32. Singleton, V.L.; Orthofer, R.; Lamuela-Raventós, R.M. Analysis of total phenols and other oxidation substrates and antioxidants by means of Folin-Ciocalteu reagent. Methods Enzymol. 1999, 299, 152-178.

33. Rodriguez-Amaya, D.B. A Guide to Carotenoid Analysis in Foods; ILSI Press: Washington, DC, USA, 2001; ISBN 1578810728.

34. Brasil ANVISA. Agência Nacional de Vigilância Sanitária. Resolução da Diretoria Colegiada—RDC; Brasil ANVISA: Brasília, Brazil, 2001; p. 43. 
35. Dos Santos, J.P. Determinação do teor de ilita em argilominerais interestratificado a partir da anállise do potássio total. Sitientibus 1998, 18, 127-141.

36. Lopes, T.J.; Quadri, M.G.N.; Quadri, M.B. Recovery of anthocyanins from red cabbage using sandy porous medium enriched with clay. Appl. Clay Sci. 2007, 37, 97-106. [CrossRef]

37. Teixeira-Neto, É.; TEIXEIRA-NETO, Â.A. Modificação química de argilas: Desafios científicos e tecnológicos para obtenção de novos produtos com maior valor agregado. Quím. Nova 2009, 32, 809-817. [CrossRef]

38. Miranda, R.; Ríos, H.; Delgado, F.; Castro, M.; Cogordán, A.; Salmón, M. Characterization of a bentonitic clay and its application as catalyst in the preparation of benzyltoluenes and oligotoluenes. Appl. Catal. Gen. 2003, 244, 217-233. [CrossRef]

39. Foletto, E.L.; Alves, C.C.A.; Porto, L.M. Regeneração e reutilização de uma argila comercial utilizada na clarificação de óleo vegetal. Cerâmica Ind. 2003, 8, 43-45.

40. Santos, P.S. Ciência e Tecnologia de Argilas, 2nd ed.; Egdar Blücher Ltda: Sao Paulo, Brazil, 1989.

41. Santos, A.G.D.; Caldeira, V.P.S.; Souza, L.D.; Oliveira, D.S.; Araujo, A.S.; Luz, G.E. Study of the thermal stability by thermogravimetry for oil, biodiesel and blend (B10) of different oilseeds. J. Therm. Anal. Calorim. 2016, 123, 2021-2028. [CrossRef]

42. Santos, A.G.D.; Souza, L.D.; Caldeira, V.P.S.; Farias, M.F.; Fernandes, V.J., Jr.; Araujo, A.S. Kinetic study and thermoxidative degradation of palm oil and biodiesel. Thermochim. Acta 2014, 592, 18-22. [CrossRef]

43. Knothe, G. Some aspects of biodiesel oxidative stability. Fuel Proc. Technol. 2007, 88, 669-677. [CrossRef]

44. Pantoja, S.S.; da Conceição, L.R.V.; da Costa, C.E.F.; Zamian, J.R.; da Rocha Filho, G.N. Oxidative stability of biodiesels produced from vegetable oils having different degrees of unsaturation. Energy Convers. Manag. 2013, 74, 293-298. [CrossRef]

45. Rodrigues, C.E.C.; Silva, F.A.; Marsaioli, A.; Meirelles, A.J.A. Deacidification of Brazil nut and macadamia nut oils by solvent extraction: Liquid-liquid equilibrium data at 298.2 K. J. Chem. Eng. Data 2005, 50, 517-523. [CrossRef]

46. Mercadante, A.Z.; Steck, A.; Rodriguez-Amaya, D.; Pfander, H.; Britton, G. Isolation of methyl (9'Z)-apo-6'-lycopenoate from Bixa Orellana. Phytochemistry 1996, 41, 1201-1203. [CrossRef]

47. Ministério da Saúde; Agência Nacional de Vigilância Sanitária. Resolução no 270, de 22 de setembro de 2005; Agência Nacional de Vigilância Sanitária: Brasília, Brazil, 2005; pp. 1-16.

48. Yokoya, F.; Antunes, A.J.; Jordão, B.A. Deterioração de castanha do Pará: II-Armazenamento das castanhas. Rev. Bras. Tecnol. 1971, 2, 117-120.

49. Queiroga Neto, V.; Bora, P.S.; Diniz, Z.N.; Cavalheiro, J.M.O.; Queiroga, K.F. Dipteryx lacunifera seed oil: Characterization and thermal stability. Ciênc. Agrotecnol. 2009, 33, 1601-1607. [CrossRef]

50. Lima, J. Vida de Prateleira de Amêndoas de Castanha de Caju em Embalagens Comerciais; Technical Note; Embrapa: Brasilia, Brazil, 2005; pp. 1-3.

51. Uzoh, C.F.; Obodo, N.J.; Onukwuli, O.D. Exploring the effect of styrene and anhydride ratio on the coating properties of non-drying vegetable oil based alkyd resin. J. King Saud Univ. Eng. Sci. 2018, 30, 12-21. [CrossRef]

52. Rossi, M.; Gianazza, M.; Alamprese, C.; Stanga, F. The effect of bleaching and physical refining on colour and minor components of palm oil. J. Am. Oil Chem. Soc. 2001, 78, 1051-1055. [CrossRef]

53. Roginsky, V.; Lissi, E.A. Review of methods to determine chainbreaking antioxidant activity in food. Food Chem. 2005, 92, 235-254. [CrossRef]

54. Ogbunugafor, H.A.; Eneh, F.U.; Ozumba, A.N.; Igwo-Ezikpe, M.N.; Okpuzor, J.; Igwilo, I.O.; Adenekan, S.O.; Onyekwelu, O. Physico-chemical and anti-oxidant properties of Moringa oleifera seed oil. J. Nutr. 2011, 10, 409-414.

55. Szydłowska-Czerniak, A.; Trokowski, K.; Karlovits, G.; Szłyk, E. Effect of refining processes on antioxidant capacity, total contents of phenolics and carotenoids in palm oils. Food Chem. 2011, 129, 1187-1192. [CrossRef] [PubMed]

(C) 2020 by the authors. Licensee MDPI, Basel, Switzerland. This article is an open access article distributed under the terms and conditions of the Creative Commons Attribution (CC BY) license (http://creativecommons.org/licenses/by/4.0/). 